\title{
AZ AUTÓIPAR GLOBÁLIS VERSENYKÉPESSÉGÉNEK ELEMZÉSE
}

\section{ANALYSIS OF GLOBAL COMPETITIVENESS OF THE AUTOMOTIVE INDUSTRY}

\author{
Jámbor Zsófia', Nagy Judit ${ }^{2}$ \\ 1PhD-jelölt, Budapesti Corvinus Egyetem Logisztika és Ellátási Lánc Menedzsment Tanszék \\ zsofia.jambor@uni-corvinus.hu \\ 2PhD, egyetemi adjunktus, Budapesti Corvinus Egyetem Logisztika és Ellátási Lánc Menedzsment Tanszék \\ judit.nagy@uni-corvinus.hu'
}

\begin{abstract}
ÖSSZEFOGLALÁS
Számos kutató alkalmazta már sikerrel Balassa Béla versenyképességet leíró indexét (megnyilvánuló komparatív előnyök - Revealed Competitive Advantage, RCA) a globális kereskedelem, különösképpen pedig az agrárszektor versenyképességének mérésére. Jelen tanulmányukban a szerzők a globális autóipar vizsgálata során használták az indexet, amely, köszönhetően a magas hozzáadott értéknek, az erősen versenyző piacnak, a magas szintű technológiának és foglalkoztatási létszámoknak, ma a világgazdaság egy igen jelentős ágazata. A cikk középpontjában a nemzetközi autóipari kereskedelem RCA-indexszel történő vizsgálata áll, de vizsgálja az index tartósságát és stabilitását is, azaz, hogy a feltárt versenyelőny mennyire változékony vagy éppen állandó az idők folyamán.

Az elemzés alapját a nemzetközi személygépjármű-export Világbank adatbázisából letöltött (HS6-szintű bontásban) adatai szolgáltatják, az 1997-2016 közötti időszakra vonatkozóan. A tanulmány számos érdekes eredménnyel zárult. Egyrészt fény derült arra, hogy habár Kína, az Egyesült Államok, Japán és Németország a személygépkocsik legnagyobb gyártói, a legnagyobb exportőrök mégis Németország, Japán és Kanada, akik a vizsgált időszakban termelésük 40 százalékát külpiacokon értékesítették. Magyarország a vizsgált index szerint gyenge komparatív előnnyel rendelkezik. A gyártási volumen a vizsgált időszak során csaknem háromszorosára nőtt hazánkban, ám az EU termelésének még mindig kicsi hányadát adja. A tíz legnagyobb exportőr ország a teljes export 71 százalékáért felelős. Másodsorban a tanulmány eredményei rámutatnak, hogy a legintenzívebb exportkereskedelem a közepes benzinmotorok (1500-3000 cm³) kategóriájában mutatható ki, amely a globális exporttevékenység több mint 40 százalékát teszi ki a vizsgált 1997-2016-os időszakban. Harmadrészt a Balassa-index-számítások azt mutatják, Spanyolország és Japán rendelkeznek a legnagyobb komparatív előnyökkel a világszintű gépjárműexport területén.
\end{abstract}

\section{ABSTRACT}

Many researchers have already applied the Revealed Competitive Advantage (RCA) index of Béla Balassa to measure global trade, and in particular the competitiveness of the agricultural sector. In the present study the authors used the index in the automotive sector which is a very important industry in the global economy, thanks to its high added value, highly competitive

${ }^{1}$ Levelező szerző 
market, high technology, and employment. The article focuses on examining global automotive trade with the RCA index, but also examines the duration and stability of the Balassa index which refers to the variability of the competitive position over time.

The analysis is based on data downloaded from World Bank's Global Passenger Car Exports database (HS6), for the period 1997-2016. The study concluded a number of interesting results. On the one hand, it is clear that although China, the United States, Japan and Germany are the largest manufacturers of passenger cars, the largest exporters are Germany, Japan and Canada, who sold 40 percent of their production in foreign markets during the period analysed. Hungary has a weak comparative advantage over the period analysed. Although the volume of production almost tripled during the period under review, our country still accounts for only a small proportion of the EU production. The ten largest exporting countries are responsible for $71 \%$ of total exports. Secondly, the results of the study show that the most intense export trade is shown in the category of spark-ignited internal combustion engines $\left(1500-3000 \mathrm{~cm}^{3}\right)$, which accounts for more than $40 \%$ of global export activity over the 1997-2016 period. Thirdly, the Balassa index calculations show that Spain and Japan have the highest comparative advantages in the world of automotive exports.

Kulcsszavak: versenyképesség, megnyilvánuló komparatív előny, autóipar, nemzetközi kereskedelem

Keywords: competitiveness, revealed comparative advantage, automotive industry, international trade

\section{BEVEZETÉS}

A versenyképesség már régóta a kutatók érdeklödésének középpontjában áll. Többféle megközelítés, értelmezés és definíció is létezik a megragadására. A versenyképességnek különböző szintjei különíthetők el, az egyik megközelítés szerint megkülönböztetnek mikro, mezo és makro versenyképességet. A mikroszintủ értelmezés a vállalati szféra szintjén vizsgálja a versenyképességet, amely így definiálható: „egy vállalat olyan termékek, szolgáltatások elóállítására képes, amelyeket a vevők szívesebben vesznek meg, mint a versenytársakét" (Wijnands et al., 2008, 3.). Tihomir Domazet $(2012,294-295$.) szerint a versenyképesség azt jelenti, hogy ,a cégek képesek folyamatosan és jövedelmező módon előállítani olyan termékeket, amelyek megfelelnek a nyílt piac követelményeinek az árak, a minőség stb. tekintetében". A mezoszintü versenyképesség sokkal inkább regionális szinten értelmezhetö, és Michael Kitson és szerzőtársai $(2004,992$.) szerint „egy régió vagy akár egy város versenyképessége úgy határozható meg mint egy sikerkritérium, amely mentén a régiók vagy városok versenyeznek egymással”. Matthew Gorton és szerzőtársai $(2013,4$.) másképp ragadják meg egy adott régió versenyképességét, mert úgy gondolják, annak feladata, „hogy vonzó és fenntartható környezetet biztosítson a vállalatoknak és a lakosoknak az élet és a munka területén egyaránt". A mezoszintủ versenyképesség tehát a mikro- és a makroszint között helyezkedik el, de nem csupán egy adott területen múködő vállalatok összversenyképességét je- 
lenti, hanem egy jóval komplexebb fogalom. A makroszintü versenyképesség, azaz a nemzetek versenyképessége Chikán Attila $(2008,25$.) szerint „,egy nemzetgazdaság azon képességét jelöli, hogy müködése során biztosítja és növeli állampolgárai jólétét a termelési tényezők fenntartható növekedése mellett. Ez a képesség abban nyilvánul meg, hogy a vállalatok és egyéb intézmények számára olyan környezetet teremt, amely olyan termékek és szolgáltatások létrehozására, felhasználására és értékesítésére képes, amelyek megfelelnek a globális verseny követelményeinek és a változó társadalmi normáknak."

Michael E. Porter (1990) szerint egy nemzet versenyképessége négy, egymással összefüggő tényezőn alapszik (gyémánt modell): erőforrásokhoz való hozzáférés feltételei, keresleti feltételek, támogató és kapcsolódó iparágak és a vállalati stratégia, struktúra és verseny.

A nemzeti szinten értelmezett versenyképesség mélyen gyökerezik a nemzetközi kereskedelem elméletében, amely arra kereste a választ, a különféle nemzetek miért is kereskednek egymással. Az erre a kérdésre adott válaszok közül legnagyobb hatást David Ricardo (1817) elmélete gyakorolta (komparatív előnyök elmélete), amely szerint az országoknak azon javak előállítására kell fókuszálniuk, amelyek esetében komparatív előnnyel bírnak.

Ricardo komparatív előnyök elméletére alapozva alkotta meg Balassa Béla (1965) az indexét (Balassa-index), amely a megnyilvánuló komparatív előnyök mérésére szolgál. A versenyképesség mérésére ugyanakkor különböző módszerek léteznek. Mivel a tanulmány a kereskedelemalapú makroszintủ versenyképességre összpontosít, a Balassa-indexet választottuk, amely képes a versenyképességet a kereskedelmi folyamatok révén megragadni.

Számos kutatás használja a megnyilvánuló komparatív előnyök elméletét a nemzetközi kereskedelem jellemzésére, de az autóipari kutatások részben hiányosak e területen. Jelen tanulmány a globális gépjármü-kereskedelem Balassa-index szerinti elemzését állította középpontjába, amellyel - mindezidáig - nem foglalkoztak még a kutatók. A cikk célja, hogy három módon is hozzájáruljon a szakirodalom fejlödéséhez. Egyrészt a vizsgált modellt egy globális iparág kulcsfontosságú terméke kapcsán alkalmazza. Másrészt a termék nagy fontossággal bír a fejlett gazdaságokban, markáns részét képezi a nemzetközi kereskedelemnek. Harmadrészt a tanulmány be kívánja azonosítani azokat a tényezőket, amelyek a komparatív előnyök mögött állnak.

A cikk a következő struktúra szerint épül fel. A téma fontosságának rövid ismertetése után röviden áttekinti a globális autóipart, bemutatva a legfontosabb trendeket, valamint a módszertant és a felhasználni kívánt adatokat. A következő rész a legfontosabb eredményeket ábrázolja, amelyeket az autóipari kereskedelmi adatok statisztikai elemzésével nyertek. Ezt követi a komparatív előnyök mintázatainak és stabilitásának értékelése. Végül, megfogalmazásra kerülnek a végső következtetések és a jövőbeli kutatások lehetséges irányai. 


\section{IRODALOMÁTTEKINTÉS}

A tanulmány célja, hogy az autóipar globális versenyképességi tényezőit feltárja, és azonosítson olyan országokat, amelyek ezen ágazatban komparatív előnnyel rendelkeznek az exportban.

Az autóiparban az elmúlt három évtizedben jelentős változások mentek végbe a termelés szervezési módszereit és a kivitelezés földrajzi megvalósulását illetően (Pavlínek, 2015). Az autóipari termelésnek földrajzi értelemben több jelentős régiója különböztethető meg: Európa (kivéve Oroszország), Észak-Amerika (Kanada, Egyesült Államok és Mexikó), Japán és Dél-Korea, a BRIC-országok (Brazília, Oroszország, India, Kína), valamint a világ többi része (RoW, Rest of the World). 2007-ben a BRIC- és a RoW-országok tettek szert a globális autóipari profit 30 százalékára, amely 2012-re 60 százalékra nőtt (URL1).

Az utóbbi évtizedek legjelentősebb trendjei közé tartozik az ágazatban a moduláris termelés bevezetése, a direkt beszállítók számának csökkentése és a termelési hálózat makroregionális szinten való megszervezése (Pavlínek, 2015).

Számos tanulmány foglalkozott már az autóipar kapcsán a megnyilvánuló komparatív előnyökkel, de más céllal, és más állt érdeklődésük középpontjában. Mahani Zainal Abidin és Wai Heng Loke (2008) megvizsgálták a maláj exportadatokat (néhány kiemelt szektorra), és arra jutottak, hogy az ország komparatív elönyökkel rendelkezik az elektronika és a gépgyártás területén, de az autóiparban nem. Esma Nur Cinicioglu és szerzőtársai (2012) Thomas Bayes hálózati modelljét használták, hogy beazonosítsák Törökország versenyképességi tényezőit. Kutatásukban azt állapították meg, hogy egy technológiafejlesztő ország sokkal versenyképesebb egy olyan országnál, ami csak megvenni tudja a technológiát. Julius Spatz és Peter Nunnenkamp (2002) tanulmányukban Németország, Japán és az Egyesült Államok megnyilvánuló komparatív előnyeit vizsgálják, amelyek a világ legnagyobb autógyártó országainak számítanak. Arra a következtetésre jutottak, hogy a globalizáció hátrányosan érintette ezen országok versenyképességét, különös tekintettel az Egyesült Államokét.

\section{MÓDSZERTAN}

A tanulmány a Balassa (1965) által megfogalmazott megnyilvánuló komparatív előnyindexen alapszik, amely a következőképpen épül fel:

$$
R C A_{i j}=\left(\frac{X_{i j}}{X_{i t}}\right) /\left(\frac{X_{n j}}{X_{n t}}\right),
$$

ahol meghatározzuk egy adott ország adott termékből realizált exportjának arányát $\left(X_{i j}\right)$ teljes exportjához $\left(X_{i t}\right)$ képest, majd ezt hasonlítjuk össze egy referen- 
cia-országcsoport adott termékböl megvalósított exportjának $\left(X_{n j}\right)$ és teljes exportjának $\left(X_{n}\right)$ arányával. Ha az $R C A$-index magasabb egynél, az adott országnak komparatív előnye van a vizsgált termék esetén a referenciaországokhoz képest, ha egynél kisebb, versenyhátrányban van.

Az eredeti indexet számos kritika érte, amelynek több oka van, de legföképpen 0-ra való aszimmetrikusságát kifogásolták, valamint, hogy nem veszi figyelembe a különféle gazdaságpolitikákat. Az aszimmetria problémája abból fakad, hogy versenyhátrány esetén az $R C A$-index 0 és 1 közötti értéket vesz fel, míg versenyelőny esetén bármilyen, 1-nél nagyobb értéket, felülértékelve ezzel az adott szektor relatív súlyát. Az állami támogatások, különösen a protekcionista gazdaságpolitika, nagy hatással vannak a nemzetközi kereskedelemre és a kapcsolódó piacokra, amelyek ugyancsak nem mérhetök a $R C A$-indexszel.

Thomas Lachlan Vollrath (1991) három lépést javasol a fenti problémák megoldására. Először, bevezeti a megnyilvánuló importelőnyindexet (Revealed Import Advantage, $R M A$-index), behelyettesítve az előbbi indexbe az importra vonatkozó adatokat, az alábbiak szerint:

$$
R M A_{i j}=\left(\frac{M_{i j}}{M_{i t}}\right) /\left(\frac{M_{n j}}{M_{n t}}\right),
$$

ahol meghatározzuk egy adott ország adott termékből realizált importjának arányát $\left(M_{i j}\right)$ teljes importjához $\left(M_{i}\right)$ képest, majd ezt hasonlítjuk össze egy referencia-országcsoport adott termékből megvalósított importjának $\left(M_{n j}\right)$ és teljes importjának $\left(M_{n}\right)$ arányával. Az $R C A$-indexhez képest az $R M A$ egy átlagos komparatív elönyt jelenít meg, feloldva ezzel az aszimmetria problematikáját. A Vollrath (1991) által javasolt második lépés a megnyilvánuló kereskedelmi előny (Revealed Trade Advantage, $R T A$ ) index létrehozása, amely egyszerü összevonása a két előbbi egyenletnek:

$$
R T A_{i j}=R X A_{i j}-R M A_{i j}
$$

Ebben az esetben a pozitív értékek jelentik a versenyelőnyt, a negatív értékek a versenyhátrányt. Harmadrészt Vollrath (1991) megalkotta a saját megnyilvánuló komparatívelőny-indexét $(R C)$, az $R C A$ - és $R M A$-indexek természetes logaritmusát véve a következők szerint:

$$
R C_{i j}=\ln R X A_{i j}-\ln R M A_{i j}
$$

Ez azért jó, mert..., és így az $R C$-index szimmetrikus 0 -ra, a pozitív értékek jelentik a komparatív előnyt. Bent Dalum és szerzőtársai (1998) szintén megoldási javaslatot tettek az $R C A$-index aszimmetriaproblémájának megoldására, megalkotva a szimmetrikus megnyilvánuló komparatívelőny-indexét, ahol $B$ az eredeti Balassa-indexet jelöli (Revealed Symmetric Comparative Advantage, $R S C A$ ):

$$
R S C A=(B-1) /(B+1) .
$$


Az RSCA -1 és 1 közötti értékeket vesz fel, a pozitív értékek jelentik a komparatív exportelőnyt, míg a 0 és -1 közötti értékek a komparatív exporthátrányt.

Amellett, hogy a statikus komparatív előnyök kiszámításra kerülnek, a stabilitás és az időtartam mérése is szükséges. Štefan Bojnec és Fertő Imre (2008) javaslatai alapján elsőként az RSCA-index stabilitása került mérésre (Markov-féle átmenet-valószínüségi mátrix), amelynek során értékelhető lesz a megnyilvánuló komparatív előny változékonysága az idő folyamán.

Emellett Bojnec és Fertő (2008) mérték az index időtartamát is, amely azt mutatja, hogy az index mekkora eséllyel marad változatlan az idő folyamán. (Az alkalmazott módszer a nem paraméteres Kaplan-Meier-függvény, amely szerint a minta $n$ darab független megfigyelési egységet tartalmaz (amit $t_{\mathrm{i}}$; $c_{\mathrm{i}}$-ként jelöltünk), ahol $i=1,2, \ldots, n$; $t_{\mathrm{i}}$ a túlélési idö, míg $c_{\mathrm{i}}$ egy cenzoráló indikátorváltozó, $C$ az $i$ megfigyelési egységre vonatkozóan $(C=1$, ha a hiba elöfordul, és 0 minden egyéb esetben). Ezenkívül feltételezhető, hogy $m<n$-szeres rögzített hiba van. Ezt követően sorba rendezzük a túlélési időket $t(1)<t(2)<\ldots<t(m)$. A formulában $n_{j}$ jelöli a hiba kockázatát $t(j)$ időpontban, $d_{j}$ pedig a megfigyelt hibák számát. A Kaplan-Meier-függvény ebben az esetben (azzal a konvencióval, hogy $\hat{S}(t)=1$, ha $t<t(1))$ :

$$
\hat{S}(t)=\prod_{t(i)<t} \frac{n_{j}-d_{j}}{n_{j}},
$$

A tanulmány a világ gépjármü-kereskedelmi adataira épül, amelyek a Világbank World Integrated Trade Solution (WITS) adatbázisából kerültek letöltésre, HS6-szintű bontásban, 1997 és 2016 között kilenc termék esetében (a termékek megjelölését lásd az 1. sz. mellékletben).

A fenti módszertannak számos korlátja említhető. A kereskedelmi adatok több okból sem teljesen megbízhatóak (a bontásban kapott adatok nem feltétlenül adják ki a teljes egészet, számos adat hiányos; az adatok osztályozás és exportbesorolás szerint változhatnak, és ugyanazon rendeltetési helyre vonatkozó importértékek sem mindig egyenlők). A Balassa-alapú indexek érzékenyek a 0 értékre, és az adatbázis tisztításakor óhatatlanul vesztek el értékes információk is.

\section{LEÍRÓ STATISZTIKÁK}

Az autóipar a leginkább globalizált iparágak egyike. Sikeresen kilábalt a 2008-as gazdasági világválságból, és az iparági profit 2012-ben 31 százalékkal haladta meg az utolsó, válság előtti év, 2007 profitját (URL1). A WTEx (URL3) információi szerint 2016-ban az autóipar valósította meg a legnagyobb exportot, felülmúlva a nyersolajkivitelből származó bevételeket is, köszönhetően az alacsony olajáraknak. 
Az autó és más közúti gépjármüvek termelését tekintve a TOP 10 ország Kína (amelynek éves termelése 2016-ban több mint 28 millió jármú volt), az Egyesült Államok, Japán, Németország, India, Dél-Korea, Mexikó, Spanyolország, Kanada és Brazília (URL2), amelyek együttesen a világ személy- és kereskedelmi jármüveinek 77 százalékát állítják elő.

A globális jármükereskedelmet tekintve Németország, Japán és Kanada voltak a legnagyobb exportőrök a vizsgált időszak alatt, 40 százalékát adva a világ autóexportjának, miközben a TOP 10 jármüexportör ország együttesen 71 százalékot képvisel (1. táblázat) (URL4).

A TOP gyártók nem feltétlenül TOP exportőrök is egyben. Az exportáló országok rangsorát olyan országok vezetik inkább, amelyeknek belső kereslete relatíve kisebb, mint az éves termelési volumenük. Ennek következtében, ha fenn akarják tartani a méretgazdaságos termelési volument, exportálniuk kell. Az olyan nagy autógyártó országok, mint Kína és India, gyorsan növekvő piaccal rendelkeznek, ezért a megtermelt járművek döntő része hazai piacon kerül értékesítésre.

1. táblázat. Top 10 gépjármüexportőr ország a világon és Magyarország (ezer US\$)

\begin{tabular}{|l|c|c|c|c|c|}
\hline \multicolumn{1}{|c|}{ Ország } & $\mathbf{1 9 9 7 - 2 0 0 1}$ & $\mathbf{2 0 0 2 - 2 0 0 6}$ & $\mathbf{2 0 0 7 - 2 0 1 1}$ & $\mathbf{2 0 1 2 - 2 0 1 6}$ & $\mathbf{1 9 9 7 - 2 0 1 6}$ \\
\hline Németország & 60717149 & 98579229 & 132868350 & 152165113 & 111082460 \\
\hline Japán & 52791714 & 76034334 & 92713321 & 91127746 & 78166779 \\
\hline Kanada & 31289701 & 34929224 & 33830236 & 45720822 & 36442496 \\
\hline Egyesült Államok & 16166998 & 24146296 & 38645973 & 53265488 & 33056189 \\
\hline Dél-Korea & 10352495 & 22697598 & 32172230 & 42140865 & 26840797 \\
\hline Egyesült Királyság & 14164343 & 21230890 & 27232504 & 38095704 & 25180860 \\
\hline Spanyolország & 16344542 & 23035898 & 28507158 & 30984570 & 24718042 \\
\hline Belgium & 10739725 & 26517532 & 27716977 & 29586107 & 23640085 \\
\hline Franciaország & 19224543 & 31027391 & 24624749 & 18832853 & 23427384 \\
\hline Mexikó & 12974355 & 13829225 & 21065940 & 31642182 & 19877926 \\
\hline Magyarország & 1023485 & 2069308 & 5104970 & 9157246 & 4338752 \\
\hline $\begin{array}{l}\text { TOP 10 országok } \\
\text { koncentrációja }\end{array}$ & $81,74 \%$ & $73,19 \%$ & $68,82 \%$ & $68,37 \%$ & $71,20 \%$ \\
\hline
\end{tabular}

Megjegyzés: Az országok az 1997-2016 közötti átlagos exportértékük szerinti csökkenő sorrendben helyezkednek el. Saját számítás a WITS (2017) adatok alapján

Magyarország az 1997-2016-ig terjedő időszak átlagában az előkelőnek mondható 19. helyen szerepelt az exportörök között, a régióból Csehország (12.), Szlovákia (14.) és Lengyelország (16.) előzi meg hazánkat (URL4). Az exporthelyezés 
azzal magyarázható, hogy hazánk több nagy autógyárral rendelkezik, melyek a jármüvek összeszerelése után döntően exportálják a kész gépjármüveket.

Termékszinten az 1500-3000 $\mathrm{cm}^{3}$ közötti hengerürtartalmú benzinmotoros gépkocsik adják a globális jármúexport 40 százalékát a vizsgált időszakban. Ezt követik a $3000 \mathrm{~cm}^{3}$-nél nagyobb motorral szerelt benzinüzemü jármüvek, amelyek további 20 százalékát teszik ki a globális exportnak. A harmadik legnagyobb részt ugyancsak 20 százalékkal a 1500-2500 cm³ közötti dízelmotorral szerelt jármüvek adják. Összességében ezek a jármücsoportok 80 százalékot képviselnek a világ exportjából, amely ugyancsak nagy koncentrációra utal.

A gépjármüexportőr országok többsége jelentős mennyiséget importál is (2. táblázat). Az Egyesült Államok például a negyedik legnagyobb jármüexportőr, ugyanakkor messze a legnagyobb importőre ugyanezen terméknek. Németország, az Egyesült Királyság, Franciaország, Kanada, Belgium és Spanyolország a TOP 10 gépjármüexportőrök és -importőrök listáján egyaránt szerepelnek, ami intenzív iparágon belüli kereskedelemre utal. Olaszország, Kína és Ausztrália ugyanakkor nem TOP exportőrök, viszont a globális autóimport jelentős hányadát adják. A globális jármúimport TOP 10 országainak koncentrációja a vizsgált periódusokban rendre $72 \%, 67 \%, 59 \%$ és $62 \%$ (URL4).

2. táblázat. Top 10 globális gépjárműimportőr ország a világon és Magyarország (ezer US\$)

\begin{tabular}{|l|r|r|r|r|r|}
\hline \multicolumn{1}{|c|}{ Ország } & $\mathbf{1 9 9 7 - 2 0 0 1}$ & $\mathbf{2 0 0 2 - 2 0 0 6}$ & $\mathbf{2 0 0 7 - 2 0 1 1}$ & $\mathbf{2 0 1 2 - 2 0 1 6}$ & $\mathbf{1 9 9 7 - 2 0 1 6}$ \\
\hline Egyesült Államok & 95061394 & 123887709 & 117575403 & 159945708 & 124117553 \\
\hline Németország & 24083525 & 35139400 & 41198893 & 45440672 & 36465622 \\
\hline Egyesült Királyság & 24403259 & 39309304 & 38965753 & 42725042 & 36350840 \\
\hline Franciaország & 15091623 & 23570259 & 33619184 & 30149391 & 25607614 \\
\hline Olaszország & 17967372 & 27861249 & 32015057 & 22438077 & 25070439 \\
\hline Kanada & 13733718 & 19165540 & 22676846 & 26369022 & 20486282 \\
\hline Belgium & 6892081 & 18665714 & 25962873 & 28472122 & 19998197 \\
\hline Kína & 645944 & 4659336 & 21631114 & 48180591 & 18779246 \\
\hline Spanyolország & 10489883 & 19448298 & 17902248 & 14175234 & 15503916 \\
\hline Ausztrália & 4417385 & 8231918 & 12952107 & 16452391 & 10513450 \\
\hline Magyarország & 686380 & 2093559 & 2256288 & 2194768 & 1807749 \\
\hline $\begin{array}{l}\text { TOP 10 országok } \\
\text { koncentrációja }\end{array}$ & $72,17 \%$ & $67,33 \%$ & $59,57 \%$ & $62,48 \%$ & $64,11 \%$ \\
\hline
\end{tabular}

Megjegyzés: Az országok az 1997-2016 közötti átlagos importértékük szerinti csökkenő sorrendben helyezkednek el. Saját számítás a WITS (2017) adatok alapján 
Hazánk importeredmények tekintetében a szerényebb, 39. helyen végzett, a régióból Lengyelország (22.) és Csehország (35.) ért el jobb helyezést (URL4). Az eredmény nem meglepő, kis piacnak számít Magyarország a világ autókereskedelmében, ezt az is alátámasztja, hogy hazánk átlagos export- és importvolumene a vizsgált időszakban lényegesen kisebb az élvonalban szereplő országokéinál.

\section{KOMPARATÍV ELŐNYÖK - MINTÁZATOKÉS STABILITÁS}

A Balassa-index számításainak elvégzésével fény derül a globális gépjármü-kereskedelem sajátosságaira (3. táblázat). Az első, amit megjegyezni érdemes, hogy Spanyolország és Japán rendelkeznek a legnagyobb komparatív előnyökkel valamennyi vizsgált időszakban a jármúexport esetén. Franciaország, Kanada és Németország ugyancsak relatíve nagy komparatív előnnyel bírnak, ám a többi korábban vizsgált ország meglehetősen változatos képet mutat. Mexikó például - annak ellenére, hogy a világ egyik legnagyobb gépjármüexportőre - általában igen alacsony komparatív elönnyel rendelkezik.

3. táblázat. Az eredeti Balassa-index a legfontosabb jármủexportőr országok és Magyarország esetén

\begin{tabular}{|l|c|c|c|c|c|}
\hline \multicolumn{1}{|c|}{ Ország } & $\mathbf{1 9 9 7 - 2 0 0 1}$ & $\mathbf{2 0 0 2 - 2 0 0 6}$ & $\mathbf{2 0 0 7 - 2 0 1 1}$ & $\mathbf{2 0 1 2 - 2 0 1 6}$ & $\mathbf{1 9 9 7 - 2 0 1 6}$ \\
\hline Németország & 1,15 & 1,18 & 1,25 & 1,54 & 1,28 \\
\hline Japán & 1,85 & 2,03 & 1,76 & 1,42 & 1,77 \\
\hline Kanada & 1,43 & 1,18 & 1,17 & 1,39 & 1,29 \\
\hline Egyesült Államok & 0,67 & 0,94 & 1,26 & 1,19 & 1,01 \\
\hline Dél-Korea & 1,17 & 1,16 & 0,95 & 0,92 & 1,05 \\
\hline Egyesült Királyság & 0,81 & 0,77 & 1,12 & 1,39 & 1,02 \\
\hline Spanyolország & 3,70 & 2,39 & 2,47 & 2,35 & 2,73 \\
\hline Belgium & 0,92 & 1,20 & 1,12 & 1,31 & 1,14 \\
\hline Franciaország & 1,26 & 1,55 & 1,37 & 1,22 & 1,35 \\
\hline Mexikó & 0,56 & 0,62 & 0,92 & 1,35 & 0,86 \\
\hline Magyarország & 0,98 & 0,78 & 1,14 & 1,2 & 1,03 \\
\hline
\end{tabular}

Saját számítások a WITS (2017) adatbázis alapján (az 1-nél nagyobb érték jelenti a komparatív előnyt)

Habár az eredmények jelentős mértékben függnek a használt módszertől (2. sz. melléklet), csak Japán és Spanyolország rendelkezik valamennyi időszakban megnyilvánuló komparatív előnnyel. Az RTA-index szerint is Japán és Spanyolország rendelke- 
zik a gépjárműexportban legnagyobb versenyelőnnyel, és ugyanerre az eredményre vezet a lnRCA- és a RSCA-indexek alkalmazása is. Az RC-index ugyanakkor Japánt és Dél-Koreát hozza ki az élen a globális jármükereskedelem terén.

Magyarország helyét megvizsgálva a komparatív előnyök, illetve hátrányok tekintetében látható, hogy komparatív hátránnyal rendelkezett hazánk egészen 2007ig, ekkortól javulás figyelhető meg, az egész időszakra számított átlagos RCA-mutató így már gyenge komparatív elönyt jelez. Ez az eredmény összhangban áll a hazánkban megtalálható gyárak megalakulásával, müködésével. A Suzuki és az Opel 1992-ben indította el bizonyos típusainak gyártását, az Audi 1998-ban kezdte meg múködését (Czakó et al., 2003), majd 2006-ban további két típus gyártásába kezdett hazánkban, és ez azóta tovább is bővült. Majd 2012-ben a Mercedes kezdte meg müködését Kecskeméten. Az elmúlt tíz évben az éves autógyártás közel 190000 db-ról 520000 darabra emelkedett (URL 5), bár ez a volumen más EU-s tagállamban gyártott személyautók volumenénél kisebb. Érdekes megfigyelés továbbá, hogy bár az EU teljes személyautó-gyártása is több mint 1,5 millió darabbal növekedett 2006 és 2016 között, az EU részesedése a világtermelésből kb. 33\%-ról jelentősen csökkent (24\%-ra), és a vezető szerepet Kína vette át (URL5).

Globális termékszinten az $1500 \mathrm{~cm}^{3}$-nél nagyobb dízelmotoros jármüvek bírnak a legnagyobb versenyképességi potenciállal, amelyet az $1000-1500 \mathrm{~cm}^{3}$-es hengerürtartalmú benzinmotoros gépkocsik követnek (4. táblázat). Meg kell jegyezni, hogy az ilyen motorral szerelt jármüvek többségét Spanyolországban és Japánban gyártják.

4. táblázat. Az eredeti Balassa-index a legfontosabb globális jármüexport termékek esetén az 1997-2016 közötti időszakban

\begin{tabular}{|c|c|c|c|c|c|}
\hline Termék & 1997-2001 & 2002-2006 & 2007-2011 & 2012-2016 & 1997-2016 \\
\hline $\begin{array}{l}\text { golfautó, hóban közlekedő jármü, } \\
\text { egyéb hasonló célú jármü }\end{array}$ & 1,01 & 0,96 & 1,17 & 1,29 & 1,11 \\
\hline benzinmotoros jármü, max. 1000 cm³ & 1,69 & 1,41 & 1,24 & 1,23 & 1,39 \\
\hline benzinmotoros jármü, $1001-1500 \mathrm{~cm}^{3}$ & 1,68 & 1,50 & 1,40 & 1,49 & 1,52 \\
\hline benzinmotoros jármü, $1501-3000 \mathrm{~cm}^{3}$ & 1,27 & 1,34 & 1,46 & 1,50 & 1,39 \\
\hline benzinmotoros jármü, $3000 \mathrm{~cm}^{3}$ felett & 1,29 & 1,32 & 1,44 & 1,51 & 1,39 \\
\hline dízelmotoros jármü, max. $1500 \mathrm{~cm}^{3}$ & 2,03 & 1,67 & 1,93 & 1,77 & 1,85 \\
\hline dízelmotoros jármü, $1501-2500$ cm³ & 1,35 & 1,34 & 1,39 & 1,42 & 1,38 \\
\hline dízelmotoros jármü, $2500 \mathrm{~cm}^{3}$ felett & 1,17 & 1,03 & 1,00 & 1,15 & 1,09 \\
\hline $\begin{array}{l}\text { egyéb személyszállító jármủ } \\
\text { (kivéve 8702-es vámtarifaszám) }\end{array}$ & 0,85 & 1,07 & 0,95 & 1,25 & 1,03 \\
\hline
\end{tabular}

Saját számítások a WITS (2017) adatok alapján 
A változékonyság foka az RSCA-indexben a Markov-féle átmenet-valószínúség mátrix segítségével került becslésre (1. ábra). Az eredmények az index relatíve alacsony mobilitását mutatják a legtöbb ország esetében a globális gépjármü-kereskedelem terén, ami stabil versenyképességi potenciálra utal az egyes nemzetek esetében. A komparatív előnyökkel rendelkező termékcsoportok több mint 70\%-a a hét országban változatlan maradt, míg a legalacsonyabb mobilitás az Egyesült Királyságra, Dél-Koreára és Spanyolországra jellemző, ami jelentős versenyt jelent az ágazatban.

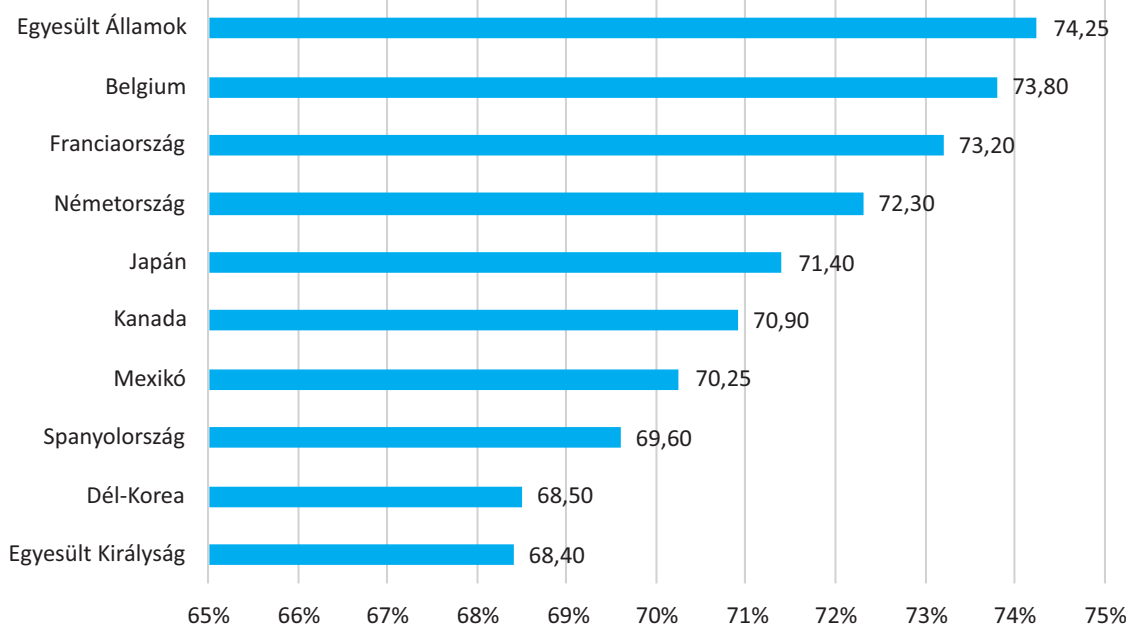

1. ábra. Az RSCA-index mobilitása az 1997-2016 közötti időszakban, országszinten (\%). Saját számítások a WITS (2017) adatok alapján

A globális gépjármüexportban elért komparatív előny tartósságát vizsgálandó a Kaplan-Meier-féle túlélési függvény (9. egyenlet) becslését végeztük el. Az eredmények megerősítik, hogy a vizsgált időszakban a túlélési idők nem tartósak (2. és 3. melléklet). A kezdeti időszak 98 százalékos versenyelőny tartóssági esélyek a záró időszakra 7-26 százalékra estek, ami a gépjármúpiacon kialakult éles versenyre utal. Az eredmények változóak ország (3. melléklet) és termékkör (4. melléklet) szerint, amiből kitűnik, a lehosszabb túlélést Németország, az Egyesült Királyság és Belgium valósította meg, míg termékszinten az $1000-1500 \mathrm{~cm}^{3}$-es és az 1500-3000 $\mathrm{cm}^{3}$-es benzinmotoros jármüvek.

\section{KÖVETKEZTETÉSEK}

A tanulmány a gépjármütermelés versenyképességét vizsgálta a nemzetközi kereskedelem kontextusában. Az elemzés számos következtetés levonását teszi lehetővé. Elsősorban, a globális gépjármü-kereskedelem jellemzőinek vizsgálatakor 
fény derült arra, hogy habár Kína, az Egyesült Államok, Japán és Németország a legnagyobb jármügyártók, a TOP exportőrök listája ettől eltér, azt Németország vezeti, amit Japán és Kanada követ a vizsgált időszakban, és amik együttesen a világ exportjának 40 százalékát realizálják, míg a TOP 10 országok együttesen 71 százalékos koncentrációt mutatnak. Az import terén ugyanakkor az látszik, hogy a legnagyobb mértékủ behozatalt az Egyesült Államok, Németország és az Egyesült Királyság valósítja meg. Magyarország a vizsgált index szerint gyenge komparatív előnnyel rendelkezik. Habár a gyártási volumen a vizsgált időszak során csaknem háromszorosára nőtt itthon, az EU termelésének még mindig kicsi hányadát adja.

Másodsorban, az elemzés feltárta, hogy a globális járműkereskedelem, -export legkeresettebb árucikke a szikragyújtású belsőégésủ motorral, $1500-3000 \mathrm{~cm}^{3}$ közötti hengerürtartalommal szerelt gépkocsi (870 323), amely 1997 és 2016 között az export 40 százalékát tette ki.

Harmadrészt, a Balassa-indexek kimutatták, hogy Spanyolország és Japán rendelkezik a legmagasabb komparatív előny értékekkel minden vizsgált időszakban a világ legnagyobb jármúexportőrei közül. Hasonló eredményt hoztak a módosított indexek is. Az RSCA-index alacsony mobilitása azt jelzi, hogy a gépjármü-kereskedelemben az egyes országok versenyképességi potenciálja stabil. A megnyilvánuló komparatív előny tartósságát vizsgálva a globális jármủexportról az mondható el, hogy a túlélési idők nem tartósak az elemzett időszakban, zuhanásuk azt igazolja, hogy a globális gépjármükereskedelemben éles verseny áll fenn. Az elemzésre épülő további kutatásokban érdemes megvizsgálni, hogy Spanyolország, Japán és Dél-Korea mire építi versenyképességét az ágazatban, ami más országok, esetleg iparágak számára is például szolgálhat.

\section{IRODALOM}

Abidin, M. Z. - Loke, W. H. (2008): Revealed Comparative Advantage of Malaysian Exports: The Case for Changing Export Composition. Asian Economic Papers, 7, 3, 130-147. http://eprints. nottingham.ac.uk/50214/

Balassa B. (1965): Trade Liberalization and Revealed Comparative Advantage. The Manchester School, 33, 99-123. DOI: 10.1111/j.1467-9957.1965.tb00050.x, https:/www.researchgate.net/ publication/229754008_Trade_Liberalisation_and_Revealed_Comparative_Advantage1

Bojnec, Š. - Fertö, I. (2008): European Enlargement and Agro-Food Trade. Canadian Journal of Agricultural Economics, 56, 4, 563-579. DOI: 10.1111/j.1744-7976.2008.00148.x, https://www. researchgate.net/publication/227788849_European_Enlargement_and_Agro-Food_Trade

Chikán, A. (2008): National and Firm Competitiveness: A General Research Model. Competitiveness Review: An International Business Journal, 18, 1-2, 20-28. DOI: 10.1108/10595420810874583, https://www.researchgate.net/publication/241702913_National_and_firm_competitiveness_A_general_research_model 
Cinicioglu, E. N. - Önsel, S. - Ülengin, F. (2012): Competitiveness Analysis of Automotive Industry in Turkey Using Bayesian Networks. Expert Systems with Applications, 39, 10923-10932. DOI: 10.1016/j.eswa.2012.03.032, https://www.academia.edu/3900940/Competitiveness_analysis_of_automotive_industry_in_Turkey_using_Bayesian_networks

Czakó E. - Gáspár J. - Jenei I. et al. (2003): Magyarország autóiparának helyzetéről az Európai Unióhoz való csatlakozást megelőzően - a csatlakozás okán várható változások. (Corvinus Kutatások 30, mühelytanulmány) Budapest: Budapesti Corvinus Egyetem, 1-40. http://edok.lib. uni-corvinus.hu/56/1/CzakoG\%C3\%A1sp\%C3\%A1r...30.pdf

Dalum, B. - Laursen, K. - Villumsen, G. (1998): Structural Change in OECD Export Specialisation Patterns: De-specialisation and 'stickiness'. International Review of Applied Economics, 12, 3, 423-443. DOI: 10.1080/02692179800000017

Domazet, T. (2012): Regional Cooperation Striving for Competitiveness and Finance. Ekonomika Preduzeća, 60, 5-6, 290-300. DOI: 10.5937/ekopre1206290D, http://see-articles.ceon.rs/data/ pdf/0353-443X/2012/0353-443X1206290D.pdf

Gorton, M. - Hubbard, C. - Fertö I. (2013): Theoretical Background and Conceptual Framework. Working paper. Halle: Leibniz Institute of Agricultural Development in Transition Economies (IAMO), 1-48. http://www.compete-project.eu/fileadmin/compete/files/working_paper/ COMPETE_Working_Paper_2_Conceptual_framework.pdf

Kitson, M. - Martin, R. - Tyler, P. (2004): Regional Competitiveness: An Elusive yet Key Concept? Regional Studies, 38, 9, 991-999. DOI: 10.1080/0034340042000320816, https://michaelkitson.files.wordpress.com/2013/02/kitson-marrtin-tyler-rs-2004.pdf

Pavlínek, P. (2015): Foreign Direct Investment and the Development of the Automotive Industry in Central and Eastern Europe. In: Galgóczi B. - Drahokoupil, J. - Bernaciak, M. (eds.): Foreign Investment in Eastern and Southern Europe After 2008. Still a Lever of Growth? Brussels: ETUI, 209-255. https://www.etui.org/content/download/21872/182679/file/Foreign+direct+investment + central + and + eastern+Europe ++ Petr + Pavl $\%$ C $3 \%$ ADnek.pdf

Porter, M. E. (1990): Competitive Advantage of Nations. Harvard Business Review, 68, 2, 73-93. http://www.economie.ens.fr/IMG/pdf/porter_1990_- the_competitive_advantage_of_nations.pdf

Ricardo, D. (1909, 1817): The Principles of Political Economy and Taxation. New York: Macmillan, https://socialsciences.mcmaster.ca/econ/ugcm/3113/ricardo/Principles.pdf

Spatz, J. - Nunnenkamp, P. (2002): Globalization of the Automobile Industry: Traditional Locations Under Pressure? Kiel Working Paper, 1093, 1-51. https://www.files.ethz.ch/isn/124240/ kap1093.pdf

Vollrath, T. L. (1991): A Theoretical Evaluation of Alternative Trade Intensity Measures of Revealed Comparative Advantage. Weltwirtschaftliches Archiv, 130, 2, 263-279. DOI: 10.1007/ BF02707986, https://www.researchgate.net/publication/24066553_A_Theoretical_Evaluation_ of_Alternative_Trade_Intensity_Measures_of_Revealed_Comparative_Advantage

Wijnands, J. H. M. - Bremmers, H. J. - Van Der Meulen, B. M. J. et al. (2008): An Economic and Legal Assessment of the EU Food Industry's Competitiveness. Agribusiness, 24, 4, 417-439. DOI: 10.1002/agr.20167

URL1: Mohr, D. - Müller, N. - Krieg, A. et al. (2013): The Road to 2020 and Beyond: What's Driving the Global Automotive Industry. McKinsey\&Company (Pub.), Automotive \& Assembly-Latest thinking. https://www.mckinsey.com/ /media/mckinsey/dotcom/client_service/ Automotive\%20and\%20Assembly/PDFs/McK_The_road_to_2020_and_beyond.ashx 1-25. (letöltve 2018. 03. 30.)

URL2: OICA.net (2017). 2016-os termelési statisztikák. http://www.oica.net/category/production-statistics/2016-statistics/ (letöltve 2018. 04. 11.) 
URL3: Workman, D. (2018): Car Exports by Country. World's Top Exports website. http://www. worldstopexports.com/car-exports-country/ (letöltve 2018. 03. 30.)

URL4: WITS - World Integrated Trade Solution Database (2017): World Bank. Nyilvános internetes adatbázis. https://wits.worldbank.org/ (letöltve 2017. 10. 05.)

URL5: EU Passenger Car Production (2018): European Automobile Manufacturers Association. https://www.acea.be/statistics/article/eu-passenger-car-production (letöltve 2018. 10. 08.)

\section{MELLÉKLETEK}

1. sz. melléklet. Autóipari termékkódok és kapcsolódó leírások HS6-szinten

\begin{tabular}{|l|l|}
\hline 870310 & jármüvek; golfautók, kifejezetten hóban közlekedésre és hasonló célra tervezett jármúvek \\
\hline 870321 & benzinmotoros jármüvek, melynek hengerürtartalma nem több mint $1000 \mathrm{~cm}^{3}$ \\
\hline 870322 & benzinmotoros járművek, $1001-1500 \mathrm{~cm}^{3}$ hengerürtartalommal \\
\hline 870323 & benzinmotoros járművek, $1501-3000 \mathrm{~cm}^{3}$ hengerürtartalommal \\
\hline 870324 & benzinmotoros járművek, $3000 \mathrm{~cm}^{3}$ feletti hengerürtartalommal \\
\hline 870331 & dízelmotoros jármüvek, melynek hengerürtartalma nem több mint $1500 \mathrm{~cm}^{3}$ \\
\hline 870332 & dízelmotoros jármüvek, $1501-2500 \mathrm{~cm}^{3}$ hengerürtartalommal \\
\hline 870333 & dízelmotoros járművek, $2500 \mathrm{~cm}^{3}$ feletti hengerürtartalommal \\
\hline 870390 & jármúvek; személyszállításra (a 8702 vámtarifaszám alá tartozók kivételével) \\
\hline
\end{tabular}

Saját összeállítás a Világbank adatbázisa alapján (2017)

2. sz. melléklet. A Balassa-indexek a legnagyobb globális jármüexportőrök esetén az 1997-2016 közötti időszakban

\begin{tabular}{|l|r|r|r|r|r|}
\hline \multicolumn{1}{|c|}{ Country } & $R C A$ & $R T A$ & $\ln R C A$ & $R C$ & $R S C A$ \\
\hline Németország & 1,28 & 0,26 & $-0,42$ & 0,02 & $-0,07$ \\
\hline Japán & 1,77 & 1,49 & 0,23 & 2,50 & 0,12 \\
\hline Kanada & 1,29 & $-0,19$ & $-2,12$ & $-1,34$ & $-0,36$ \\
\hline Egyesült Államok & 1,01 & 0,06 & $-1,02$ & 0,36 & $-0,24$ \\
\hline Dél-Korea & 1,05 & 0,77 & $-0,79$ & 2,24 & $-0,19$ \\
\hline Egyesült Királyság & 1,02 & $-0,42$ & $-0,31$ & $-0,40$ & $-0,11$ \\
\hline Spanyolország & 2,73 & 1,44 & 0,04 & 0,24 & 0,05 \\
\hline Belgium & 1,17 & $-0,58$ & $-0,16$ & $-0,33$ & $-0,05$ \\
\hline Franciaország & 1,35 & $-0,27$ & $-0,47$ & $-0,48$ & $-0,11$ \\
\hline Mexikó & 0,86 & 0,46 & $-2,49$ & $-0,12$ & $-0,38$ \\
\hline
\end{tabular}

Saját számítások a WITS- (2017) adatbázis alapján 


\begin{tabular}{|c|c|c|c|c|c|c|c|c|c|c|c|}
\hline - & $\circ$ & & & & & & & & & & \\
\hline 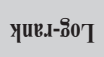 & 0 & & & & & & & & & & \\
\hline ڤั & $\bar{z}$ & $\overline{\sigma^{2}}$ & $\frac{2}{0}$ & 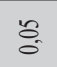 & gे & 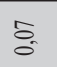 & : & $=$ & तु & $\stackrel{2}{0}$ & $\therefore$ \\
\hline 望 & ন্ & के & 商 & $\stackrel{ \pm}{0}$ & $\frac{9}{0}$ & $\bar{g}$ & 要 & da & 嘉 & तु & $\stackrel{9}{0}$ \\
\hline ग्ञ & $\frac{8}{8}$ & 웅 & 尤 & $\overline{\bar{\sigma}}$ & 경 & $\underset{c}{\infty}$ & $\frac{\infty}{2}$ & 壱 & F & 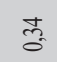 & ta \\
\hline 商 & 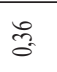 & fo. & 耏 & $\bar{c}$ & ח. & $\bar{c}$ & F. & 舟 & $\overrightarrow{5}$ & 웅 & वें \\
\hline ิี & F. & fo. & 8 & त्ă & 亦 & ?. & 秦 & 웅 & 家 & 舫 & 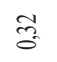 \\
\hline $\bar{\Xi}$ & 是 & $\stackrel{\tilde{B}}{0}$ & E. & $\hat{a}$ & 웡 & 舟 & F & त्व & 8 & g. & 学 \\
\hline ปิ & : & : & $\stackrel{2}{\circ}$ & f & 웅 & हू. & $\overrightarrow{3}$ & \% & 8 & 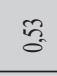 & के \\
\hline క్సి & : & 8 & E. & 乐 & : & $\stackrel{\infty}{\circ}$ & : & : & 8 & $\sqrt{5}$ & 表 \\
\hline \%) & 要 & 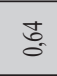 & $\overrightarrow{\sigma_{0}}$ & 8 & 言 & to & $\overline{8}$ & 8 & E. & $\bar{D}_{0}$ & 果 \\
\hline ) & 8 & 8 & : & 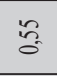 & : & $\stackrel{8}{\circ}$ & 8 & $\stackrel{8}{0}$ & $\stackrel{5}{\circ}$ & 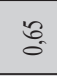 & 8 \\
\hline 高 & $\bar{b}_{0}$ & है & $\ddot{2}$ & के & $\stackrel{8}{8}$ & $\therefore$ & 8 & 웅 & $\begin{array}{l}\infty \\
\stackrel{0}{0} \\
0\end{array}$ & 8 & 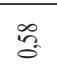 \\
\hline 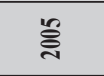 & $\begin{array}{ll}\vec{E} \\
\dot{0}\end{array}$ & E. & $\stackrel{8}{\infty}$ & 䒯 & 㕝 & $\therefore$ & $\stackrel{5}{8}$ & $\stackrel{8}{\circ}$ & : & $\tilde{s}$ & 8 \\
\hline 壳 & I & : & : & $\stackrel{8}{\circ}$ & 5 & 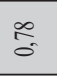 & 8 & $\mathscr{0}_{0}$ & : & $\stackrel{0}{0}$ & $\stackrel{8}{\circ}$ \\
\hline 䓂 & 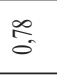 & 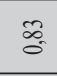 & 8 & $\stackrel{8}{0}$ & E & $\stackrel{\infty}{\infty}$ & $\stackrel{8}{0}$ & $\stackrel{8}{\infty}$ & 总 & $\frac{5}{0}$ & $?$ \\
\hline క్ & $\vec{s}$ & $\stackrel{0}{\circ}$ & S. & E. & $\stackrel{\circ}{0}$ & 8 & E. & : & : & $:$ & E. \\
\hline Е్ & $\ddot{\infty}$ & $\stackrel{\infty}{\circ}$ & : & s. & $\stackrel{\circ}{:}$ & $\stackrel{\infty}{\infty}$ & : & s. & $\therefore$ & $\stackrel{\infty}{\infty}$ & 唐 \\
\hline క్ & $\stackrel{\infty}{\infty}$ & $\stackrel{8}{\circ}$ & : & $\ddot{\circ}$ & : & $\stackrel{\infty}{\infty}$ & $\stackrel{\infty}{\infty}$ & : & : & $\stackrel{\infty}{\infty}$ & $\ddot{\circ}$ \\
\hline まे & S. & : & g. & $\stackrel{8}{\infty}$ & $\stackrel{\infty}{\infty}$ & S. & S. & g. & $\therefore$ & s. & : \\
\hline$\stackrel{2}{2}$ & ga & 䒯 & : & : & S: & a & a & $\therefore$ & s. & 菏 & 8 \\
\hline 玉 & 5 & 5 & $\stackrel{\infty}{\circ}$ & $\therefore$ & $\stackrel{8}{\circ}$ & s. & 5 & $\stackrel{\infty}{\circ}$ & $\stackrel{\infty}{\circ}$ & 5 & 5 \\
\hline 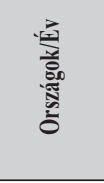 & 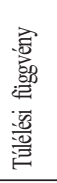 & 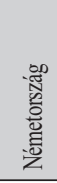 & 量 & 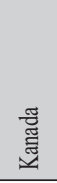 & 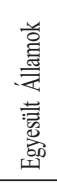 & 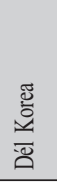 & 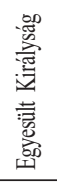 & 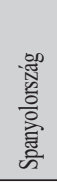 & 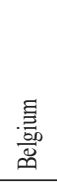 & 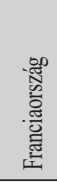 & $\frac{.0 .0}{\frac{3}{2}}$ \\
\hline
\end{tabular}




\begin{tabular}{|c|c|c|c|c|c|c|c|c|c|}
\hline 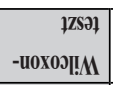 & $\circ$ & & & & & & & & \\
\hline 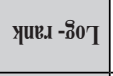 & 0 & & & & & & & & \\
\hline ؛ั & 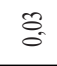 & $\stackrel{ \pm}{0}$ & a & $\stackrel{5}{c}$ & $\stackrel{s}{0}$ & $\stackrel{\circ}{\circ}$ & $\equiv$ & 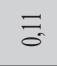 & $\stackrel{\circ}{g}$ \\
\hline 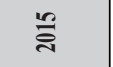 & $\frac{2}{0}$ & $\stackrel{8}{8}$ & 哭 & $\overline{3}$ & 궁 & $\frac{a}{0}$ & तु & 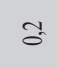 & $\frac{\infty}{0}$ \\
\hline 喜 & శ్ & हु & to & to & ; & : & $\tilde{g}_{0}^{2}$ & $\stackrel{a}{\sigma}$ & శ్తి \\
\hline ڤิ & శ్ & da & 寿 & F & 孛 & $\overline{3}$ & बें & 营 & $\underset{\sigma}{\infty}$ \\
\hline 亏ี & 架 & 素 & 舫 & 8 & \pm & $\vec{a}$ & 表 & aे & $\tilde{c}_{0}$ \\
\hline$\overline{\bar{\alpha}}$ & 夈 & 舫 & 8 & $\stackrel{\infty}{\infty}$ & 乎 & ? & 慗 & 麦 & ia \\
\hline ڤ్ & 乎 & 蒙 & हn & 8 & fo & $\frac{\alpha}{\alpha}$ & $\vec{n}$ & 番 & to \\
\hline ड్ & g. & à & $\vec{b}_{0}$ & 5 & $\Omega_{0}^{2}$ & 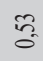 & a. & 荾 & 靑 \\
\hline ڤ్ & : & 总 & 8 & ra & $\sqrt{5}$ & 5 & $\stackrel{\square}{0}$ & के & 否 \\
\hline 气े & $\sqrt{5}$ & $\stackrel{5}{0}$ & $\stackrel{8}{\circ}$ & 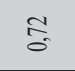 & $\Xi_{0}^{\Xi}$ & $\Xi_{0}^{\circ}$ & $\stackrel{t}{\mathrm{~g}}$ & $\stackrel{8}{8}$ & 孛 \\
\hline ثั & $\stackrel{8}{0}$ & $\overline{0}$ & $\stackrel{2}{0}$ & $\stackrel{n}{0}$ & to & $\stackrel{\circ}{\circ}$ & 8 & 8 & so \\
\hline క్ & $\stackrel{\circ}{\circ}$ & 売 & $\stackrel{0}{0}$ & $\stackrel{\infty}{0}$ & $\stackrel{\circ}{\circ}$ & $=$ & E. & E. & 营 \\
\hline క్⿱宀 & $\bar{s}$ & E. & : & $\underset{\dot{\infty}}{\overrightarrow{0}}$ & $\stackrel{2}{0}$ & I & 志 & 声 & $\stackrel{8}{\circ}$ \\
\hline 䓂 & $\frac{I}{\sigma}$ & g. & $\stackrel{8}{0}$ & $\stackrel{\mathscr{B}}{\mathscr{B}_{0}}$ & E & E: & $\stackrel{\infty}{0}$ & $\stackrel{\infty}{0}$ & $\stackrel{8}{8}$ \\
\hline కิ & $\stackrel{\infty}{0}$ & : & $\stackrel{\ddot{\alpha}}{\circ}$ & $\ddot{\infty}$ & $\stackrel{\dot{\infty}}{\dot{s}}$ & $\stackrel{\infty}{\stackrel{\infty}{\infty}}$ & $\ddot{\circ}$ & $\stackrel{\infty}{\circ}$ & $E$ \\
\hline Е్ & $\ddot{8}$ & $\stackrel{\circ}{\circ}$ & $\stackrel{\infty}{\infty}$ & : & 壳 & 8 & $\because$ & $\because$ & $\overrightarrow{\vec{g}_{0}}$ \\
\hline క్ష & $\stackrel{\circ}{\circ}$ & $\stackrel{\infty}{\infty}$ & $\stackrel{8}{\circ}$ & $\stackrel{\circ}{\circ}$ & $\stackrel{\infty}{\infty}$ & $\stackrel{8}{\circ}$ & $\stackrel{\Delta}{a}$ & $\stackrel{\infty}{-\infty}$ & $\therefore$ \\
\hline बे & $\stackrel{8}{8}$ & : & : & : & s. & $\therefore$ & : & s. & $\stackrel{\infty}{\circ}$ \\
\hline$\stackrel{\circ}{\circ}$ & ga & ga & : & : & 苛 & ga & 营 & 莺 & 8 \\
\hline 玉 & : & s. & : & s. & : & 5 & : & : & : \\
\hline 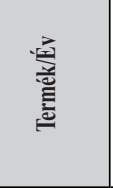 & 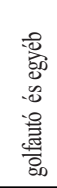 & 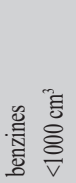 & 言 & 言 & 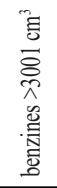 & $\frac{\overline{2}}{y}$ & 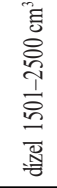 & 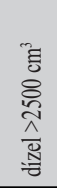 & 猷 \\
\hline
\end{tabular}

